\title{
In Search of Outcomes of a Psychological Contract in Public Organisation
}

Agata Bera*† https://orcid.org/0000-0003-3296-6697

*Jagiellonian University, Cracow, Poland. Email: agata.bera@doctoral.uj.edu.pl

Abstract

Background. Sustainable development of employees is based primarily on practices oriented towards caring for the relationship between the employer and employee. In this approach, the employee's and the employer's perception of mutual obligations, the employee's belief in the conditions for the exchange of mutual experiences with the employer, and mutual obligations resulting from establishing an employer-employee relationship become important factors and elements of the sustainable development strategy of employees. A growing number of soundscape studies involve a psychological contract literature. However, outcomes have not yet been thoroughly reviewed. The need for a study with this purpose is proven by the fact that academic literature lacks a systematic review of this topic, despite the ascending trend in the number of published articles in the field. Therefore, this study aims at identifying the main outcomes of a psychological contract in public organisations.

Research aims. The purpose of this literature review was to identify the main effects of psychological contracting in public organisations. We also aimed to collect fragmented academic knowledge produced by pertinent studies.

Methodology. This article adopts the Preferred Reporting Items for Systematic Reviews and Meta-Analyses (PRISMA) approach to conduct the systematic literature review. The final sample of 41 empirical and conceptual studies were scientifically screened and synthesised.

Findings. This study establishes that a psychological contract is a complex phenomenon influencing individual, group, and organisational outcomes directly. The application of a systematic literature review demonstrates the importance of a psychological contract for public organisations. The review suggests an agenda for further research and identifies practical implications for public organisations.

Keywords

psychological contract, public organisation, outcome, systematic literature review

\section{INTRODUCTION}

Contemporary public organisations are expected to be efficient, responsive, effective, and economical in action (Knies et al., 2018). This, in turn, forces them to change their logic and management methods, in particular to focus on human resource management practices. The research conducted so far has shown that employees' behaviour, motivation, job satisfaction, commitment, loyalty, relationships, ties, and identification with the organisation are essential for coping with the challenges and expectations posed to public organisations (Brunetto et al., 2020). In this context, a psychological contract is gaining importance (Tekleab et al., 2020) as an unwritten agreement between the employee and the employer, an idiosyncratic set of mutual promises, and expectations and obligations of the employee and the organisation (Rousseau, 1989). A psychological contract covers socio-emotional and non-monetary exchanges based on trust and loyalty (relational contract), tangible cash rewards (transactional contract), mutual learning and development (sustainable contract), and the consequences of organisational changes on the maintenance of preestablished employment conditions (transitional contract) (Rousseau, 1989; Rousseau et al., 2013).

Research on a psychological contact in management sciences has been conducted intensively for over 60 years (Tekleab et al., 2020). This concept was developed by Argyris (Argyris 1961) and propagated by Rousseau (Rousseau, 1989). Initially, a psychological contract was recognised in the literature in the context of psychological therapy. It was only in the 1980s that the research burden was transferred to the organisation, and a psychological contract began to be understood as the perception by the employee and the

\footnotetext{
${ }^{+}$Corresponding author
} 
employer of mutual obligations, the employee's belief in the conditions for the exchange of mutual experiences with the employer, and mutual obligations resulting from establishing an employer-employee relationship (Tekleab et al., 2020).

The investigations so far in the area of a psychological contract in the context of public organisations have focused on behaviour, violation, perception, and shaping of the psychological contract. A psychological contract was linked to organisational change, outsourcing, restructuring, efficiency, civic behaviour, organisational support, job satisfaction, organisational cynicism, employee relations, employee motivation, organisational justice, and employability and employee involvement (Casado \& Caspersz, 2019). Research on psychological contracts in the context of the public sector has so far been carried out in local government units, public finance, social welfare, public utilities, public transport, schools, health care facilities, the army, the police, universities, government bodies and fire brigades (Duran et al., 2018). The literature emphasises that further research on a psychological contract should be conducted in the context of employees exposed to factors influencing their somatic and mental wellbeing (Duran et al., 2018), in particular in fire brigades (Boselie et al., 2021). At the same time, it is indicated that violation of a psychological contract by fire brigade employees may result in a loss of sense of security, deterioration of well-being, emotional exhaustion, distancing, deterioration of relations with colleagues, lack of commitment, distrust, dissatisfaction, and resignation from work (Duran et al., 2018). Despite the high research intensity, a psychological contract of employees of public organisations is still an original and cognitively interesting subject, as the research results so far are still inconclusive, in particular its individual, group, and organisational outcomes (Coyle-Shapiro et al., 2019).

To overcome the above weaknesses, we conduct a systematic literature review to map the field and systematically identify gaps. Therefore, our review addresses the following research question:

Q1. What are the outcomes of psychological contract in public organisations?

This study aims to identify the main outcomes of a psychological contract in public organisations. Bridging this gap has important theoretical and practical implications. Theoretically, our review provides new insights on different characteristics of outcomes of the psychological contract in public organisations. First, we start with setting up a conceptual boundary so that we could confine the definition of a psychological contract. Second, we summarise the methodology that is used to systematically select and review the literature, with details of our search strategy, analysis, and assessment of the quality of the studies provided. Third, we report our findings of our systematic literature review, followed by outcomes of a psychological contract. In practice, our systematic literature review can help develop a reliable knowledge base by accumulating knowledge from a range of studies (Tranfield et al., 2003). Finally, we discuss the implications and limitations of our studies and suggest some key areas for future research direction.

\section{PSYCHOLOGICAL CONTRACT}

The term psychological contract was first introduced in the 1960s (Argyris, 1960). Levinson et al. (1962) presented the psychological contract as a set of five elements that include the following:

1) unspoken, "silent" expectations,

2) building expectations before starting formal cooperation,

3) mutual dependence of contract partners,

4) psychological distance, not hindering cooperation, but allowing to maintain independence,

5) dynamics, meaning the possibility of making changes without agreeing with partners.

Schein (1965) also contributes to the development of the psychological contract. In Organizational Psychology Schein wrote that a psychological contract means that "individuals have a wide variety of expectations from the organisation, and the organisation has many expectations of them."

The psychological contract is most closely related to the research carried out by Rousseau in 1989. In his work psychological contract is defined as "beliefs, based on expressed or implied promises, about a contract of exchange between the individual and ... the employing company and its contractors" (Rousseau, 1989). A psychological contract is made up of mutual expectations and beliefs between the employer and employee that may be derived from previous experiences, unspoken expectations, or promises. These expectations relate, for example, to job security or access to benefits and resources (Ho, 2005; Johnson \& Bharadwaj, 2005; Montes \& Zweig, 2009), to relational benefits provided by companies, as well as to the individual motivation associated with them (Aggarwal \& Bhargava, 2010; Montes \& Irving, 2008; O'Leary-Kelly et al., 2014). According to Rousseau 
(Rousseau, 2004), psychological contracts and people who participate in their exchanges may be dominant. In the literature on the subject, psychological contracts are divided into two main types: relational contracts and transactional contracts, which Rousseau supplements with transitional and balanced contracts (Rousseau, 1995). Relational contracts are those that include long-term and extensive commitments, based on the exchange of socio-emotional components such as loyalty, commitment, and trust (Raja et al., 2004; Robinson et al., 1994; Rousseau, 1990; Rousseau \& Parks, 1993). Trading contracts are those that have an economic basis and are short-term (Morrison, 1997; Robinson 1997; Raja et al., 2004; Rousseau, 1990). Rousseau (1990) argues that people who have a transactional contract are characterised by "high competitive wage rates and a lack of organisational commitment" (391). A transitional psychological contract is characterised by low employee confidence in the organisation caused by low wages and uncertainty about the future actions of the employer, as well as an imprecise incentive system (Rousseau, 2000). A balanced psychological contract occurs when employees offer the organisation their loyalty and commitment in exchange for the prospect of secure employment. The compensation received by the employee depends on his professional achievements (Rousseau, 1995).

There are many definitions of a psychological contract in the literature. Another definition of a psychological contract is "the belief of an individual that there are mutual obligations between that person and another party, such as the employer" (Rousseau \& Tijoriwala, 1998). In A Dictionary of Human Resource Management (Heery \& Noon, 2001), a psychological contract is defined as "the beliefs of each of the parties involved in a cooperative relationship about what the individual offers and what the organisation offers [...]. Unlike an employment contract, a psychological contract is not written and changes over time as new expectations arise about what employees should offer and what they can expect in return."

The following definitions of the psychological contract are presented by George (2009):

- "The psychological contract is hidden, implied in the sense that it is unspoken, unwritten, and often only reveals itself when breached."

- "Psychological contracts are reciprocal in nature and are rooted in beliefs about mutual obligations in the employeeemployer relationship; they concern the exchange of agreements between individuals and organizations."

At its core, a psychological contract is a concept that describes the nature of the employee-employer relationship. These relations undergo constant and significant changes, which are shaped mainly by the flexible forms of employment that are present today.

\section{METHOD}

This article adopts the Preferred Reporting Items for Systematic Reviews and Meta-Analyses (PRISMA) approach to conduct the systematic literature review, which differs from traditional literature reviews in that it is more replicable and transparent, involving several explicit steps, such as using a standardised way to identify all the likely relevant publications (Moher et al., 2009). The systematic literature review aims at reducing some bias by having clearly formulated research questions and employing explicit, rigorous, and accountable methods. This predetermined explicit method is comprehensive, and it involves rigorous criteria and tools that filter out irrelevant articles and mitigate the bias in question.

First, we limit our review of the literature published between 1989 and January 2021. The starting date includes the first appearance of the concept of a psychological contract in literature (Rousseau, 1989). Then, we search for peer-reviewed English-language articles in the databases Scopus and Web of Science, the most frequently used in the field of business and management as academic publication searching sources. We employed Preferred Reporting Items for Systematic Review and Meta-Analyses (PRISMA) (Moher et al., 2009) to identify eligible studies. The articles had to meet the following six criteria to be included in the review:

1. Topic: The studies included need to provide details on the outcomes of a psychological contract in public organisations.

2. Topic: Only empirical studies were eligible for the literature review (literature reviews and conceptual works were not included), because we are interested in empirical evidence concerning science crowdsourcing. All research projects were acceptable (e.g., questionnaire, case study, experiment), but case studies that were purely illustrative were excluded. We also excluded systematic reviews (Van Beurden et al., 2021) to avoid double-counting of the research. Conference papers or proceedings, article reviews, book chapters, and unpublished theses and dissertations were not included.

3. Language: Only publications written in English were taken into account.

4. Year of publication: Articles that were published between 1989 and January 2021 were searched and included.

5. Publication types: Only international, peer-reviewed, full-text publications were included. 
Second, we chose a narrow and fuzzy search criterion by using keywords (psychological contract*), (outcomes*) and (public organisation*) in the "title" of academic articles. This strategy resulted in a total of 64 articles (Scopus: 40; Web of Science: 24). Next, by means of analysing the title, research issues, and key conclusions in the abstracts of these selected articles, we selected the most relevant to the field of a psychological contract. Finally, the abstracts were checked regarding the inclusion criteria. During this stage, we identified and eliminated 49 duplicate studies. The eligibility criteria and the search strategies ultimately lead to 41 studies for our systematic review. Our assessment and selection process is presented in Figure 1.

\section{RESULTS}

General characteristics of studies. Before answering our research question, we address some characteristics of the studies included in our review. Figure 2 presents the evolution of the number of studies until February 2021. As can be seen, the number of articles published remained fairly constant from 2006 to 2021, at roughly 3 articles per year (41 articles in 14 years). However, the period 2013 to 2015 showed a considerable increase. This is a very clear indication of the rapid recent growth in research on psychological contract in the public sector.

Third, $36 \%$ of studies included in the review were conducted in USA. The UK was the second-most studied country (19\%). Australia was the third-most studied (4\%). Although most of the articles (87\%) studied Western countries, we also found a limited number of studies conducted in Asia and the Middle East. On the other hand, only eight (13\%) articles made crosscountry comparisons, revealing a lack of such studies within the literature.

Outcomes of psychological contract. In this section, we present findings of these 41 identified scientific works. Based on our systematic analysis of the sample articles, we classified the outcomes of the psychological contract each of the studies focused on into three categories: individual, group, and organisational.

Individual outcomes. Of the identified articles, 18 refer to individual benefits. The latest research comes from 2021 and concerns testing of a conceptual model, the task of which is to investigate the indirect effect of security motivation associated with a psychological contract (Vatankhah, 2021). The oldest studies in this group are from 2006. Their aim was to examine the content and condition of the psychological contract from the perspective of the employee and the employer, as well as to examine the reciprocity of duties (Coyle-Shapiro \& Kessler, 2000). Further studies on individual benefits appear in 2007 and investigate the relationship between IS staff reduction and employee performance related to IT outsourcing (Outlay, 2007) and the impact of breaking a psychological contract on 8 work-related outcomes (Zhao et al., 2007). In 2011, research was conducted on the moderating role of the Is-Lam work ethic and the ratio of adversity over the relationship between psychological breach of contract and various outcomes at the employee level (job satisfaction, employee involvement and intention to quit) (Bukhari et al., 2011) Research by Walker (2013) concerned the analysis of the effects of violating and fulfilling a psychological safety contract. Lu et al. (2015) conducted a study aimed at analysing the role of the moderator in the leader-member exchange in the relationship between psychological breach of contract (PCB) and employee performance in China. In 2016, research was conducted on the analysis of the relationship between the implementation of a psychological contract and affective commitment as well as normative commitment and job satisfaction (Pohl et al., 2016). A study from Zagenczyk et al. (2017) related to demonstrating, using the theory of characteristics and psychological contact, that narcissism is a personality trait that manifests itself in the form of starting and neglecting when employees experience psychological breaking of contracts of the part of employer. The largest number of studies on individual benefits occurs in 2018. They concerned reassessment and reevaluation of the psychological contract, the impact of honesty and integrity on the psychological contract (Jackson, 2019); examining the beliefs and experiences of firefighters about the psychological contract between the employer, stress in the workplace, stress management strategies and their well-being (Duran et al., 2018); a review of research on the psychological contract from the earliest to the present, and an indication of the directions of future research (Coyle-Shapiro et al., 2019); and examination of the relationship between workplace bullying and employee performance (intention quitting work, job satisfaction, and commitment to work) in violation of the psychological contract (Rai \& Agarwal, 2018). In 2019, there were studies on examining the moderate influence of conscience model on the mediator role of the psycho-logical breaking of contracts (PCV) in the relationship between interactive injustice and EVLN employees (exit, voice, loyalty, and neglect) using the mediation model (Rai \&Agarwal 2020) and to examine the relationship between the fulfilment of a psychological contract by the employer and employees' attitudes (job satisfaction, organisational commitment, and the intention to leave the organisation) (Estreder et al., 2019). The key issue connecting all of the above publications is the "psychological contract." The limitations of the research in this group were mainly related to the fact that despite the popularity of research on psychological contracts in recent years, few still compare the results and their correctness and most of the research was conducted cross-sectionally. 


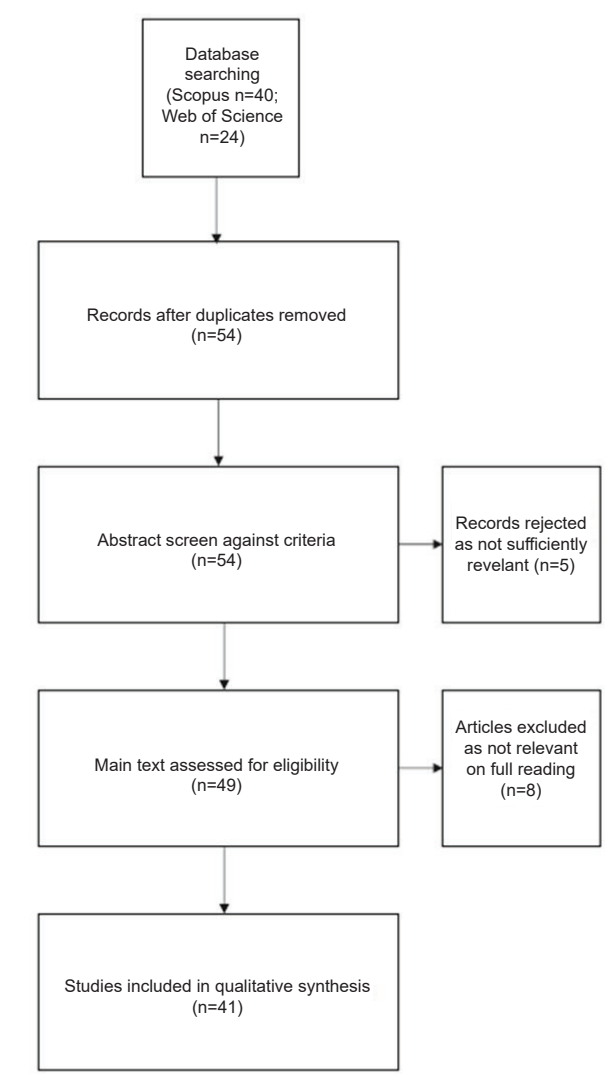

Figure 1. PRISMA flow diagram. Source: Author's own description.

Group outcomes. Only 6 of the selected publications relate to group benefits. The first one comes from 2015 and examines the effects of violating a psychological contract among traders (Hartmann \& Rutherford, 2015). Another relates to the study of the interactive impact of violating psychological contracts (PCV) and the exchange of leader members (LMX) on behaviours and attitudes in the workplace (Biswas, 2016). Research conducted by Restubog et al. (2007) concerns testing the impact of breaking psychological contracts on several work results: deviant behaviour in the workplace directed at the organisation (WD$\mathrm{O}$ ) and its members (WD-I) and the results at work in the workplace and civic behaviour directed at the organisation (OCB-O) and its associates (OCB-I). This group also included the publication by Coyle-Shapiro et al. (2019) on a review of research on psychological contract. The 2019 publication was about comparing the results with the expectations of students, universities, and non-profit organisations, using the theory of psychological contract and proposing a benefit model (Haski-Leventhal et al., 2019). The most recent publication among the selected ones on group benefits is from 2020 , and its purpose was to examine the psychological contract concluded with doctors who are not consultant doctors, to gain insight into their job satisfaction and well-being, and to determine the impact of violating a psychological contract on job satisfaction and employee well-being (Collins \& Beauregard, 2020). The limitations of the research mainly related to the fact that it focused on specific groups and dimensions of the psychological contract, as a result of which other interesting research areas were not explored.

Organisational outcomes. Out of 38 identified articles, 15 relate to group benefits. The oldest of them come from 2008, and they investigate the relationships between the violation of the psychological contract and specific outcomes variables such as organisational commitment, job satisfaction and organisational civic behaviour (Cantisano et al., 2008) and the relationship between the types of psychological contracts (transactional, balanced, and relational) and organisational performance (intention to quit work and civic behaviour directed at the organisation) and the various mechanisms by which types of psychological 


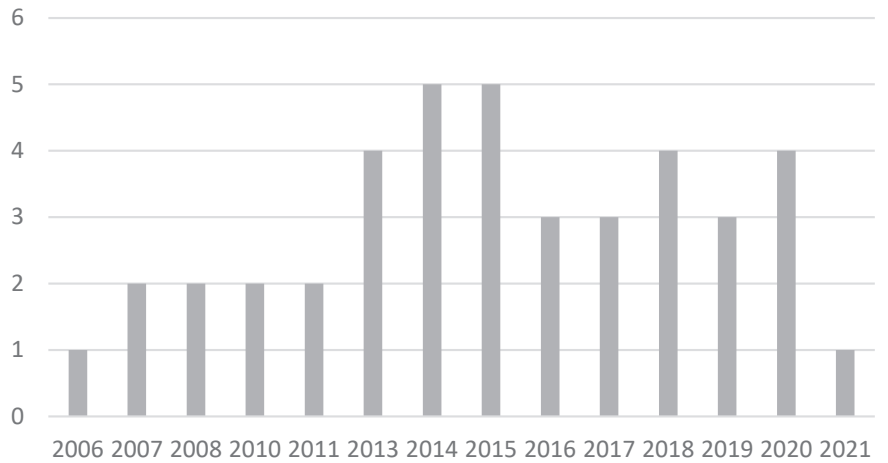

Figure 2. Year of publication for articles included in the systematic review. Source: Author's own description.

contracts systematically influence organisational performance (Yin \& Xu, 2008). Two publications also come from 2010: Arshad and Sparrow (Arshad \& Sparrow, 2010), whose aim was to investigate the antidepressant model and the consequences of violating the psychological contract caused by employment reduction and Luchak and Pohler (2010), which concerned the development of a prognosis concerning moderating the impact of the importance that employees attribute to their marginal costs of leaving their job, as well as the role of perception of residence and saving effects, on different work outcomes under a defined benefit pension In this study, they examine the effects of marginal quit costs, stayer perceptions, and saver effects under a defined-benefit pension plan on staying intentions, work effort, job performance, and discretionary behavior. Research conducted by Haq et al. (2011) related to examining the relationship between psychological contract, emotional commitment, and work performance (job satisfaction and intention to quit the job). The aim of Eckerd et al. (2013) was to describe the role of psychological contracts in the supply chain and to investigate when and how the three conditions of violating a psychological contract-attribute, severity and time-negatively affect the results. Also in 2013, Massingham published and article that investigated the relationship between a number of contextual factors and psychological contract measures in order to identify differences in approach and behaviour in the face of a large organisational change initiative aimed at building the capacity of a learning organisation (2013), and Katou wrote on the impact of HR practices on organisational performance through the mediating role of the psychological contract (2013). A publication by Guest (2014) was devoted to analysing and reviewing the evidence for the relationship between temporary contracts and a selected contract, psychological contract and job security. In 2015, 3 publications were published on organisational benefits. The first concerned the analysis of the relationship between the psychological contract and sales (Finch et al., 2015); another referred to integration of the labor and resource demand model and the psychological contract within the framework of the social exchange theory (Birtch et al., 2015); and the aim of the last one was to investigate the role of the mediator in violating the psychological contract (PC) in the relationship between perceived organisational support (POS) and the set of work-related interactions (trust) (Paillé, 2015). Costa and Neves (2017) conducted research on the relationship between job insecurity and individual performance and whether job insecurity is positively and/ or negatively related to job performance. As with individual and group benefits, there is also an overview of research on the psychological contract (Coyle-Shapiro et al., 2019). The latest publication from among those selected is from 2020; its aim was to investigate macroeconomic factors that can alleviate the psychological relationship between a breach of contract (PCB) and the result of work (Jayaweera et al., 2020). The limitations of the research mainly related to the cross-sectional approach, which limited the possibility of drawing firm conclusions about the cause-effect relationship between the variables. The data collected in the above studies came mainly from a single source, which was also a limitation.

\section{CONCLUSIONS}

The purpose of this systematic review was to identify the main outcomes of a psychological contract in public organisations. In doing conducting this review, our goal was to integrate the fragmented academic knowledge produced by pertinent studies. Moreover, the paper offered a research avenue to enhance further our understanding of outcomes. To gain some clear empirical understanding of the literature on outcomes of psychological contract, we conducted a systematic review that addressed the 
following research question: Q1. What are the outcomes of psychological contract in public organisations? Our findings show that outcomes have more than one dimension, and thus they are more complex and dynamic than have hitherto been reported. First, the literature indicates that among individual outcomes of a psychological contract, one can distinguish motivation, maintaining employment, employee performance, increasing productivity, maintaining ethical behaviour, job satisfaction, emotional and normative employee involvement, and intention to stay in the organisation. In addition, it is distinguished by honesty and reliability in the performance of official duties, well-being, and reducing stress at work. Second, with regard to group outcomes of psychological contract one can distinguish: cooperation with others and civic behaviour. Finally, with regard to the organisational outcomes of psychological contract, the following are indicated: organisational results measured by reducing the costs of employees leaving work, building the organisation's ability to learn, job security, and an increase in sales profits. This article gives public sector managers an insight into the difficulties they may face in maintaining a psychological contract. It should be recognised that maintaining a psychological contract has a decisive influence on the management of a public organisation. Previous investigations in the area of psychological contracts in the context of public organisations combine it with organisational changes, outsourcing, restructuring, efficiency, civic behaviour, organisational support, job satisfaction, organisational cynicism, employee relations, employee motivation, organisational justice and employability, and employee commitment (Casado \& Caspersz, 2019). The management of a public organisation should remember that violation of a psychological contract by firefighters may result in a loss of sense of security, deterioration of well-being, emotional exhaustion, distancing oneself, deterioration of relations with co-workers, lack of commitment, distrust, dissatisfaction, and resignation from work (Duran et al., 2018). This study can help public organisations become more aware of the potential outcomes of psychological contracts. These findings also lead us to a future research program on the outcomes of psychological contracts in public organisations. First, we propose that future research into the outcomes of psychological contracts should encompass all aspects of those outcomes and, in particular, the interdependencies between the outcomes. Second, research should focus on the nature of individual outcomes of psychological contracts due to the fact that a psychological contract is a set of mutual, unwritten expectations that exist between individual employees and their employers. This all refers to employee relations. Psychological contracts consist of mutual obligations and expectations between the employer and employee. In addition, there is a lack of research on the outcomes of a different type of psychological contract in public organisations. This study is the first detailed review of the outcomes of psychological contract in public organisations.

\section{LIMITATIONS}

Our study has limitations. First, we used two databases in the systematic literature review: Scopus and Web of Science. They are quite extensive, but they have their limitations, which may have resulted in some studies being omitted. Second, only Englishlanguage publications were included in the study, which may have narrowed down the results of the systematic literature review. Third, our searches were limited only to the outcomes. However, the study did help to provide a lot of useful information from the point of view of public organisations. Finally, as we emphasised, the literature has mainly focused on Western countries. This forced our study to depend on the cultural context. Despite these limitations, this article provides a means of better understanding the complex nature of the outcomes of psychological contracts for researchers and practitioners alike.

\section{ACKNOWLEDGMENTS}

The authors would like to kindly thank the Editors and Reviewers of the paper for their comments and help in the review process.

\section{REFERENCES}

Aggarwal, U., \& Bhargava, S. (2010). Predictors and outcomes of relational and transactional psychological contract. Psychological Studies, 55(3), 195-207.

Argyris, C. (1960). Understanding organizational behavior. Dorsey Press.

Argyris, C. (1961). Explorations in consulting-client relationships. Human Organization, 20(3), 121-133.

Arshad, R., \& Sparrow, P. R. (2010). Downsizing and survivor reactions in Malaysia: Modelling antecedents and outcomes of psychological contract violation. International Journal of Human Resource Management, 21(11), 1791-1813. 
Birtch, T. A., Chiang, F. F. T., \& Van Esch, E. (2015). A social exchange theory framework for understanding the job characteristics-job outcomes relationship: The mediating role of psychological contract fulfillment. The International Journal of Human Resource Management, 27(11), 1-20.

Biswas, S. (2016). Behavioral and attitudinal outcomes of psychological contract violation. Journal of Management Development, 35(2), 1-32.

Boselie, P., Van Harten, J., \& Veld, M. (2021). A human resource management review on public management and public administration research: Stop right there... before we go any further... Public Management Review, 23(4), 483-500.

Brunetto Y., Beattie R. (2020). Changing role of HRM in the public sector, Public Management Review, 22:1, 1-5

Bukhari, T. A. S., Saeed, M. M., \& Nisar, M. (2011). The effects of psychological contract breach on various employee level outcomes: The moderating role of Islamic work ethic and adversity quotient. African Journal of Business Management, 5(21), 8393-8398.

Cantisano, G., Domínguez J. F., \& Depolo, M. (2008). Psychological contract breach and outcomes: Combining meta-analysis and structural equation models. Psicothema, 20(3), 487-496.

Casado, R., \& Caspersz, D. (2019). Changing psychological contracts and organisational commitment: A longitudinal comparison of assigned and self-initiated expatriates in Australia. The International Journal of Human Resource Management. doi: 10.1080/09585192.2019.1660701.

Collins, A., \& Beauregard, A. (2020). The effect of breaches of the psychological contract on the job satisfaction and wellbeing of doctors in Ireland: A quantitative study. Human Resources Health, 18(89).

Costa, S., \& Neves, P. (2017). Job insecurity and work outcomes: The role of psychological contract breach and positive psychological capital. Work \& Stress, 31(4), 375-394.

Coyle-Shapiro, J. A.-M., Costa, S. P., Doden, W., \& Chang, C. (2019). Psychological contracts: Past, present, and future. Annual Review of Organizational Psychology and Organizational Behavior, 6, 145-169.

Coyle-Shapiro, J. A.-M., \& Kessler, I. (2000). Consequences of the psychological contract for the employment relationship: A large scale survey. Journal of Management Studies, 37(7), 903-930.

Duran, F., Woodhams, J., \& Bishopp, D. (2018). An interview study of the experiences of firefighters in regard to psychological contract and stressors. Employee Responsibilities and Rights Journal, 30, 203-226.

Eckerd, S., Hill, J., Boyer, K. K., Donohue, K., \& Ward, P. T. (2013). The relative impact of attribute, severity, and timing of psychological contract breach on behavioral and attitudinal outcomes. Journal of Operations Management, 31, 567-578.

Estreder, Y., Tomás, I., Chambel, M. J., \& Ramos, J. (2019). Psychological contract and attitudinal outcomes: Multilevel mediation model. Personnel Review, 48(7), 1685-1700.

Finch, D., Hillenbrand, C., O'Reilly, N., \& Varella, P. (2015). Psychological contracts and independent sales contractors: An examination of the predictors of contractor-level outcomes. Journal of Marketing Management,31(17-18), 1-41.

George, C. (2009). The psychological contract: Managing and developing professional groups. Open University Press.

Guest, D. (2014). Flexible employment contracts, the psychological contract and employee outcomes: An analysis and review of the evidence. International Journal of Management Reviews, 5/6(1), 1-19.

Haq, U. I., Jam, F. A., Azeem, M. U., Ali, M. A., \& Fatima, T. (2011). Psychological contract and job outcomes: Mediating role of affective commitment. African Journal of Business Management, 5(19), 7972-7979.

Hartmann, N. N., \& Rutherford, B. N. (2015). Psychological contract breach's antecedents and outcomes in salespeople: The roles of psychological climate, job attitudes, and turnover intention. Industrial Marketing Management, 51, 158-170.

Haski-Leventhal, D., Paull, M., Young, S., Maccallum, J., Holmes, K., Omari, M., Scott, R., \& Alony, I. (2019). The multidimensional benefits of university student volunteering: Psychological contract, expectations, and outcomes. Nonprofit and Voluntary Sector Quarterly, $49,1-21$.

Heery, E., \& Noon, M. (2001). A dictionary of human resource management. Oxford University Press.

Ho, V. T. (2005). Social influence on evaluations of psychological contract fulfillment. Academy of Management Review, 30(1), 113-128.

Jackson, N. (2019). Psychological contract. In Organizational justice in mergers and acquisitions (pp. 279-304). Palgrave Macmillan.

Jayaweera, T., Bal, M., Chudzikowski, K., \& de Jong, S. (2020). The impact of economic factors on the relationships between psychological contract breach and work outcomes: A meta-analysis. Employee Relations, 43(3), 667-686.

Johnson, D. S., \& Bharadwaj, S. (2005). Digitization of selling activity and sales force performance: An empirical investigation. Journal of the Academy of Marketing Science, 33(1), 3-18.

Katou, A. A. (2013). The link between HR practices, psychological contract fulfilment, and organisational performance in Greece: An economic crisis perspective. Journal of Industrial Engineering and Management (JIEM), 6(2), 568-594.

Knies, E., Paul Boselie, P., Gould-Williams, J., \& Vandenabeele, W. (2018). Strategic human resource management and public sector performance: Context matters. The International Journal of Human Resource Management. doi: 10.1080/09585192.2017.1407088.

Levinson, H., Price, C. R., Munden, K. J., Mandl, H. J., \& Solley, C. M. (1962). Men, management and mental health. Harvard University Press.

Lu, Y., Shen, Y., \& Zhao, L. (2015). Linking psychological contract breach and employee outcomes in China: Does leader member exchange make a difference? The Chinese Economy, 48(4), 297-308. 
Luchak, A. A., \& Pohler, D. M. (2010). Pensions as psychological contracts: Implications for work outcomes. Industrial Relations: A Journal of Economy and Society, 49, 61-82.

Massingham, P. (2013). The relationship between contextual factors, psychological contract and change outcomes. Strategic Change, 22(3-4), 157-173.

Moher, D., Liberati, A., Tetzlaff, J., \& Altman, D. G. (2009). Preferred reporting items for systematic reviews and meta-analyses: The PRISMA statement. BMJ, 339, 2535.

Montes, S. D., \& Irving, P. G. (2008). Disentangling the effects of promised and delivered inducements: Relational and transactional contract elements and the mediating role of trust. Journal of Applied Psychology, 93(6), 1367-1381.

Montes, S. D., \& Zweig, D. 2009. Do promises matter? An exploration of the role of promises in psychological contract breach. Journal of Applied Psychology, 94(5), 1243-1260.

Morrison, E., Robinson, S. (1997). When employees feel betrayed: A model of how psychological contract violation develops. Academy of Management Review, 22(1), 226-256.

O'Leary-Kelly, A. M., Henderson, K. E., Anand, V., \& Ashforth, B. E. (2014). Psychological contracts in a non-traditional industry: Exploring the implications for psychological contract development. Group \& Organization Management, 39(3), 326-360.

Outlay, C. N. (2007). Resizing information systems personnel after IT outsourcing: Exploring psychological contracts, violations, and employee outcomes. SIGMIS CPR '07.

Paillé, P. (2015). Perceived organizational support and work outcomes: The mediating role of psychological contract violation. International Journal of Organizational Analysis, 23(2).

Pohl, S., Bertrand, F., \& Ergen, C. (2016). Psychological contracts and their implications for job outcomes: A social exchange view. Military Psychology, 28(6), 1-29.

Rai, A., \& Agarwal, U. A. (2018). Examining workplace bullying-outcomes relationships among Indian managers: Psychological contract violation as mediator and workplace friendship as moderator. Employee Relations, 40(6), 1015-1035.

Rai, A., \& Agarwal, U. A. (2020). Linking interactional injustice to EVLN outcomes: Effects of psychological contract violation and conscientiousness (a moderated mediation model). International Journal of Organizational Analysis, 28(2), 488-506.

Raja, U., Johns, G., \& Ntalianis, F. (2004). The impact of personality on psychological contracts. Academy of Management Journal, 47(3), 350-367.

Restubog, S. L. D., Bordia, P., \& Tang, R. L. (2007). Behavioural outcomes of psychological contract breach in a non-Western culture: The moderating role of equity sensitivity. British Journal of Management, 18, 376-386.

Robinson, S. L., Kraatz, M. S., \& Rousseau, D. M. (1994). Changing obligations and the psychological contract: A longitudinal study. Academy of Management Journal, 37(1), 137-152.

Rousseau, D. M. (1989). Psychological and implied contracts in organizations. Employee Responsibilities and Rights Journal, $2,121-139$.

Rousseau, D. M. (1990). New hire perceptions of their own and their employer's obligations: A study of psychological contracts. Journal of Organizational Behavior, 11, 389-400.

Rousseau, D. M. (1995). Psychological contracts in organizations: Understanding written and unwritten agreements. Sage Publications.

Rousseau, D. M. (2000). Psychological contract inventory technical report. Heinz School of Public Policy, and Graduate School of Industrial Administration, Carnegie Mellon University.

Rousseau, D. M. (2004). Psychological contracts in the workplace: Understanding the ties that motivate. The Academy of Management Executive, 18(1), 120-127.

Rousseau, D. M., \& Parks, I. M. (1993). The contracts of individuals and organizations. Research in Organizational Behavior, 15, 41-43.

Rousseau, D. M., \& Tijoriwala, S. A. (1998). Assessing psychological contracts: Issues, alternatives and measures. Journal of Organizational Behavior, 19, 679-695.

Rousseau, D. M., Tomprou, M., \& Montes, S. D. (2013). Psychological contract theory. Sage.

Schein, E. H. (1965). Organizational psychology. Prentice-Hall.

Tekleab, A. G., Laulié, L., De Vos, A., De Jong, J. P., \& Coyle-Shapiro, J. A.-M. (2020). Contextualizing psychological contracts research: A multi-sample study of shared individual psychological contract fulfilment. European Journal of Work and Organizational Psychology, 29(2), 279-293.

Tranfield, D., Denyer, D., \& Smart, P. (2003). Towards a methodology for developing evidence informed management knowledge by means of systematic review. British Journal of Management, 14, 207-222.

Van Beurden, J., Van De Voorde, K., \& Van Veldhoven, M. (2021). The employee perspective on HR practices: A systematic literature review, integration and outlook. The International Journal of Human Resource Management, 32(2), 359-393.

Vatankhah, S. (2021). Dose safety motivation mediate the effect of psychological contract of safety on flight attendants'safety performance outcomes?: A social exchange perspective. Journal of Air Transport Management, 90.

Walker, A. (2013). Outcomes associated with breach and fulfillment of the psychological contract of safety. Journal of Safety Research, 47, $31-37$. 
Yin, J. L., \& Xu, C. W. (2008). Notice of retraction: The empirical research of the relationships between psychological contract types and organizational outcomes. 4th International Conference on Wireless Communications, Networking and Mobile Computing, Dalian, China, pp. 1-5. doi: 10.1109/WiCom.2008.1694.

Zagenczyk, T. J., Smallfield, J., Scott, K. L., Galloway, B., \& Purvis, R. L. (2017). The moderating effect of psychological contract violation on the relationship between narcissism and outcomes: An application of trait activation theory. Frontiers in Psychology, 8, 1-10. doi: 10.3389/ fpsyg.2017.01113.

Zhao, H., Wayne, S., Glibkowski, B. C., \& Bravo, J. (2007). The impact of psychological contract breach on work-related outcomes: A metaanalysis. Personnel Psychology, 60(3), 647-680. 